\title{
Saliva as an Early Detection Tool for Chronic Obstructive Pulmonary Disease Risk in Patients with Periodontitis
}

\author{
Tiara Oktavia Saputri, Hayu Qommaru Zala, Bramita Beta Arnanda, Retno Ardhani \\ Faculty of Dentistry, Gajah Mada University, Yogyakarta, Indonesia \\ Correspondence to: tearakuw@yahoo.com
}

\begin{abstract}
Chronic Obstructive Pulmonary Disease (COPD) is a serious respiratory disease that causes death. World Health Organization (WHO) estimates that in 2020, COPD is responsible the fourth cause of death worldwide. Early detection of COPD is important because of its progressive characteristic and difficulty in treatment. Diagnosis of COPD is based on positive results from expectorated sputum, but contamination by oropharyngeal bacteria would cause false negative results. Overcoming this possible disadvantage of procedure would need alternative biological material for diagnosis. Periodontitis has been known to be one of the risk factors of COPD. Periodontitis has been linked to the presence of Porphorymonas gingivalis, sialidase enzyme, and interleukin (IL) 8 in the saliva. These markers have also been correlated COPD, therefore saliva has potential use as biological material harboring the markers of COPD in patients with periodontitis. This review focused on analysis of the potential use of saliva as an alternative biological material for early detection of COPD in patients with periodontitis. Full range of information obtained from journals, textbooks and online scientific articles was obtained. Saliva is suggested as promising biological material for early detection of COPD in patients with periodontitis.
\end{abstract}

\begin{abstract}
Abstrak
Saliva sebagai material deteksi dini penyakit paru obstruktif kronis (PPOK) pada pasien dengan periodontitis. Penyakit Paru Obstruktif Kronis (PPOK) merupakan salah satu penyakit pernafasan yang berbahaya dan dapat menyebabkan kematian. Perkiraan World Health Organization (WHO) pada tahun 2020, PPOK akan menjadi penyebab kematian keempat di seluruh dunia. Deteksi dini PPOK sangat dipentingkan karena penyakit ini cepat berkembang dan sulit diobati. Diagnosis kerja PPOK didasarkan pada pemeriksaan positif dari sputum, namun kontaminasi sputum dengan bakteri orofaring dapat menyebabkan hasil negatif palsu. Diperlukan alternatif material biologis yang dapat memecahkan masalah tersebut. Periodontitis telah diketahui sebagai salah satu faktor resikot terjadinya PPOK. Beberapa penanda biologis terjadinya periodontitis seperti Porphorymonas gingivalis, enzim sialidase dan interleukin (IL-8) terdapat dalam saliva. Penanda tersebut juga telah dihubungkan dengan PPOK, oleh karena itu saliva mempunyai potensi sebagai material biologis yang memiliki banyak penanda adanya PPOK pada pasien dengan periodontitis. Studi pustaka ini memaparkan analisis penggunaan saliva sebagai material biologis alternatif untuk deteksi dini PPOK pada pasien dengan periodontitis. Berbagai informasi dari jurnal, buku teks dan artikel dari internet digunakan sebagai bahan acuan tulisan ini. Saliva mempunyai potensi sebagai material biologis untuk deteksi dini PPOK pada pasien dengan periodontitis.
\end{abstract}

Keywords: chronic obstructive pulmonary disease, saliva, Porphorymonas gingivalis, sialidase, IL-8.

\section{PENDAHULUAN}

Penyakit paru obstruktif kronis (PPOK) adalah salah satu penyakit pernafasan yang dapat menyebabkan kematian dan ditemukan secara luas di masyarakat. ${ }^{1}$ Penyakit paru obstruktif kronis merupakan penyakit paru kronik yang ditandai oleh hambatan aliran udara di saluran napas yang bersifat progresif reversibel parsial atau non-reversibel.$^{2}$ Pada tahun 1998, World Health Organization (WHO) menyatakan bahw PPOK merupakan penyebab kematian kelima dan semakin meluas di berbagai negara dan diperkirakan. Namun di tahun tahun 2020 diperkirakan akan menjadi penyebab kematian keempat di seluruh dunia. ${ }^{3}$ Prevalensi PPOK di beberapa ne- 
gara berkisar 9- 10\%. Di Indonesia, prevalensi PPOK adalah sebesar 5,6\%. ${ }^{4}$ Meskipun demikian, PPOK masih sering diremehkan baik oleh petugas kesehatan maupun oleh penderita. $^{5}$

Penyakit paru obstruktif kronis dihubungkan dengan kesehatan mulut, secara signifikan individu dengan kebersihan mulut yang buruk memiliki indeks oral hygiene $(\mathrm{OH})$ yang tinggi. ${ }^{1}$

Suatu penelitian menunjukkan bahwa derajat kebersihan rongga mulut dapat menggambarkan apakah seorang pasien akan beresiko menderita infeksi saluran napas. ${ }^{6}$

Untuk mengendalikan insidensi PPOK, beberapa program deteksi dini diterapkan dalam populasi yang mempunyai faktor resiko. ${ }^{5}$ Salah satu faktor resiko yang diketahui adalah individu dengan periodontitis. ${ }^{1}$ Deteksi dini PPOK yang saat ini banyak dilakukan adalah melalui pemeriksaan sputum pada penderita. Namun, terdapat keterbatasan pada kultur sputum sebagai alat diagnostik tunggal untuk mencari penyebab PPOK. ${ }^{3}$

Saliva sangat berperan dalam kondisi kesehatan rongga mulut. Anatomi rongga mulut dan organ-organ pernafasan saling berhubungan satu sama lain. Adanya hubungan anatomi ini menyebabkan dimungkinkannya terjadi penyakit pernafasan yang disebabkan karena kondisi rongga mulut maupun sebaliknya. ${ }^{7}$ Berdasarkan uraian tersebut, dapat diartikan pula bahwa terdapat hubungan antara organ-organ pernafasan dengan saliva yang ada di rongga mulut. Oleh karena itu, saliva dapat digunakan sebagai deteksi dini resiko PPOK pada penderita periodontitis. Tujuan studi pustaka ini adalah untuk mengetahui potensi penggunaan saliva sebagai deteksi dini resiko PPOK pada penderita periodontitis dengan mengetahui kandungan saliva yang dapat digunakan sebagai deteksi dini resiko PPOK.

\section{Penyakit paru obstruktif kronis}

Penyakit paru obstruktif kronis merupakan penyakit paru kronik yang ditandai oleh hambatan aliran udara di saluran napas yang bersifat progresif non reversibel atau reversibel parsial. Penyakit paru obstruktif kronis terdiri dari bronkitis kronik dan emfisema atau gabungan keduanya. Bronkitis kronik ialah kelainan saluran napas yang ditandai oleh batuk kronik berdahak minimal 3 bulan dalam setahun, sekurang- kurangnya dua tahun berturut - turut, dan tidak disebabkan penyakit lainnya. ${ }^{2}$ Sedangkan emfisema yakni suatu kelainan anatomis paru yang ditandai oleh pelebaran rongga udara distal bronkiolus terminal, disertai kerusakan dinding alveoli, dan hilangnya kelenturan dinding alveolus yang menyebabkan udara yang masuk kedalam paru tidak dapat dikeluarkan dengan baik dan terperangkap di dalam paru. ${ }^{8}$ Bronkitis kronik merupakan hasil dari iritasi pada cabang bronkiolus yang menyebabkan peningkatan proporsi sel penghasil mukus dalam epithelium. Sel tersebut mensekresikan mukus sisa trakeobronkiolus yang cukup untuk menimbulkan batuk berdahak. Salah satu faktor yang berperan pada resiko penyakit PPOK penyakit periodontitis. ${ }^{1}$

\section{Periodontitis}

Periodontitis merupakan inflamasi kronis yang disebabkan adanya infeksi bakteri pada jaringan periodontal yang terdapat dalam plak gigi, menyebabkan hancurnya jaringan tulang pendukung dan jaringan ikat. Bakteria subgingival yang ditemukan pada penyakit periodontitis kronis antara lain Porphorymonas gingivalis, Actinobacillus actinomycetemcomitans, Prevotella intermedia, dan Bacteroides forsythus. ${ }^{1}$ Hingga saat ini belum ada riset yang menegakkan bahwa penyakit periodontal mempengaruhi patofisiologi PPOK, dan hanya sedikit penelitian yang menunjukkan bahwa terdapat hubungan diantara keduanya. ${ }^{6}$ Dari beberapa data menunjukkan bahwa pada individu penderita PPOK memiliki oral hygiene index (OHI) lebih tinggi dibandingkan individu sehat. Seseorang 
dengan nilai OHI maksimum, menunjukkan bahwa ia memiliki kebersihan rongga mulut yang tergolong buruk dan beresiko menderita PPOK. ${ }^{9}$

\section{Kondisi saliva di rongga mulut}

Saliva berperan penting pada kesehatan gigi dan rongga mulut. Saliva merupakan cairan yang terdiri dari sekresi kelenjar ludah dan cairan krevikular gingiva. Terdapat $90 \%$ saliva diproduksi oleh kelenjar ludah mayor, antara lain: kelenjar parotis dengan sekresi cairan serosa, kelenjar submandibula dan kelenjar sublingual dengan sekresi cairan seromukosa. Sekitar 10\% saliva diproduksi oleh kelenjar ludah minor yang terdapat pada mukosa rongga mulut di bagian lingual, labial, bukal, palatinal, dan glossopalatinal. Pada rongga mulut dengan kondisi sehat, volume saliva tiap harinya berkisar antara 500 $\mathrm{ml}$ hingga 1,5 liter. ${ }^{10}$ Pada saliva mengandung beberapa elektrolit $(\mathrm{Na}+, \mathrm{K}+, \mathrm{Cl}-, \mathrm{HCO} 3-$, $\mathrm{Ca} 2+, \mathrm{Mg} 2+, \mathrm{HPO} 42-, \mathrm{SCN}-$, dan F-), protein (amilase, musin, histatin, cystatin, peroxidase, lisozim, dan laktoferin), immunoglobulin (sIgA, Ig G, dan Ig M), molekul organik (glukosa, asam amino, urea, asam uric, dan lemak). ${ }^{10,11}$ Fungsi saliva adalah memulai pencernaan, mempermudah proses menelan dengan membasahi partikel-partikel makanan; memiliki efek antibakteri melalui efek ganda, pertama oleh lisozim (suatu enzim yang melisiskan atau menghancurkan bakteri tertentu) dan kedua dengan membilas bahan yang mungkin digunakan bakteri sebagai sumber makanan; membantu kita berbicara dengan mempermudah gerakan bibir dan lidah. $^{12}$

\section{Hubungan PPOK dan saliva pada penderita periodontitis}

Suatu penelitian menunjukkan bahwa derajat tingkat kebersihan rongga mulut dapat menggambarkan pada pasien apakah ia akan beresiko untuk menderita infeksi saluran napas ataupun tidak. Buruknya $\mathrm{OH}$ seseorang dapat meningkatkan jumlah dan kompleksitas plak gigi yang mengandung bakteri mulut penyebab infeksi paru-paru. $P$. gingivalis penyebab periodontitis dilepaskan dari plak gigi masuk ke dalam sekresi saliva, yang kemudian akan teraspirasi ke saluran nafas bawah dan menyebabkan infeksi kemudian berinteraksi dengan bakteri patogen pada saluran napas $P$. aeruginosa, Klebsiella pneumonia. ${ }^{6}$ Sitokin dari jaringan penyakit periodontal dapat masuk ke dalam saliva melalui cairan crevicular gingiva dan diaspirasi untuk merangsang proses inflamasi kronik yang berkontribusi pada inisiasi infeksi paru-paru, termasuk PPOK (Gambar 1). ${ }^{1}$

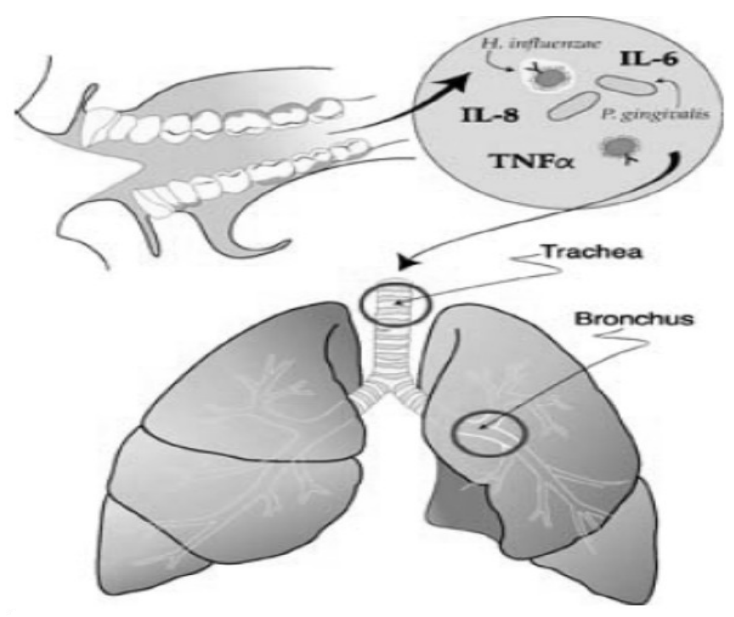

Gambar 1. Bakteri rongga mulut dan infeksi saluran nafas. ${ }^{1}$

\section{Porphorymonas gingivalis dalam saliva}

P.gingivalis merupakan bakteri gram negatif, non-motil, berbentuk rod dan patogenik anaerob, yang terdapat di rongga mulut dan berkaitan dengan lesi jaringan periodontal, infeksi, dan penyakit periodontal pada usia dewasa. ${ }^{13}$ Pada subjek dengan penyakit periodontal diketahui mempunyai plak gigi dalam jumlah yang cukup tinggi sehingga meningkatkan level bakteri seperti $P$. gingivalis dan $P$. spyrocheta. $P$. gingivalis memproduksi enzim protease yang dapat mengubah permukaan mukosa reseptor adhesi pada bakteri patogen saluran nafas seperti $H$. influenza. Enzim tersebut juga dapat mendegradasi molekul saliva yang secara normal merupakan bentuk sebuah pelikel pada patogen, dimana dapat mencegah perlekatan 
bakteri patogen terhadap permukaan mukosa. Pelikel saliva yang terdegradasi tersebut menyebabkan terbukanya reseptor adhesi untuk pathogen, sehingga aktivitas dari enzim protease ini adalah meningkatkan adhesi dan kolonisasi dari bakteri patogen saluran nafas. ${ }^{1}$

\section{Enzim sialidase dalam saliva}

Enzim sialidase (enzim neuraminidase) adalah suatu enzim yang menghidrolisa residu asam sialat terminal dari sialioglycoconjugates. ${ }^{14}$ Penyakit periodontal berhubungan dengan enzim yang dapat menghancurkan pelikel saliva pada bekteri patogen. Saliva terdiri dari beberapa enzim hidrolitik, dan sejumlah aktivitas dari enzim hidrolitik pada saliva berhubungan dengan kebersihan mulut dari subjek yang diuji. Pada PPOK, subjek dengan kebersihan mulut yang buruk menyebabkan meningkatnya level enzim hidrolitik seperti sialidase dalam saliva. Enzim tersebut memproses mucin untuk mengurangi kemampuannya untuk berikatan dan membersihkan bakteri patogen. Kebalikannya, enzim tersebut memproses epithelium respiratori untuk mengatur adhesi dari pathogen terhadap permukaan mukosa. Dalam beberapa studi menyebutkan bahwa bakteri rongga mulut dapat memecah komponen saliva, selain itu enzim hidrolitik dapat menghancurkan komponen pertahanan seperti mucin, sehingga mengurangi pertahanan spesifik untuk melawan bakteri pathogen pada saluran nafas. ${ }^{1}$

\section{Interleukin- 8 dalam saliva}

Dikatakan bahwa IL-8 adalah suatu kemokin yang diproduksi oleh makrofag dan sel lainnya dan fungsi utamanya adalah menginduksi kemotaksis neutrofil. ${ }^{15}$ Pada PPOK jumlah IL-8 dominan dan bersifat selektif pada neutrofil. Observasi pada PPOK didapatkan kerusakan pada epitel saluran nafas akibat adanya pelepasan proinflamasi sitokin berupa IL-8 dari epithelium saluran pernafasan, sehingga terjadi pengerahan dan infiltrasi neutrofil, serta pelepasan enzim proteolitik dan oksigen radikal yang bersifat toksik dari neutrofil. Pada bakteri rongga mulut dalam sekresi yang berkontak dengan permukaan epitel saluran nafas dan kemungkinan melekat pada permukaan mukosa. Adanya ikatan dengan bakteri rongga mulut menyebabkan adanya stimulus produksi sitokin oleh epitel mukosa, yang kemungkinan sitokin juga dihasilkan dari jaringan mulut seperti cairan krevikular gingiva yang keluar dari sulkus gingiva dan bercampur dengan saliva, sehingga terjadi kontaminasi pada epithelium saluran nafas bagian distal. Sel epitel yang terangsang akan melepaskan sitokin lain untuk mengerahkan sel-sel radang seperti neutrofil. ${ }^{1}$ Interleukin-8 yang disekresi oleh sel epitel gingival meningkatkan pengaturan ekspresi reseptor adhesi pada permukaan mukosa untuk mendorong terjadinya kolonisasi bakteri pathogen saluran nafas. ${ }^{6}$

\section{Deteksi dini PPOK}

Deteksi dini ialah usaha untuk mengidentifikasi atau mengenali penyakit atau kelainan yang secara klinis belum jelas, dengan menggunakan uji, pemeriksaan, atau prosedur tertentu yang dapat digunakan secara cepat untuk membedakan individu yang kelihatannya sehat, benar-benar sehat, dan yang tampak sehat tetapi sesungguhnya menderita kelainan. Deteksi dini PPOK yang saat ini banyak dilakukan adalah melalui pemeriksaan pada sputum pada penderita. Pemeriksaan sputum digunakan untuk deteksi PPOK pada kondisi stabil atau eksaserbasi. ${ }^{16}$ Metode yang dilakukan dengan menganalisis sampel sputum dari pasien dengan kondisi PPOK yang moderat sampai parah, dan variable yang digunakan adalah pengukuran terhadap penghitungan sel dan level interleukin-6 (IL-6) dan IL-8. Dari metode tersebut menunjukkan bahwa terjadi peningkatan level IL-6 dan IL-8 selama eksaserbasi, yang mengindikasi bahwa pasien dengan level yang lebih tinggi dari sitokin pada sputum mempunyai frekuensi eksaserbasi yang sering terjadi. Level IL-6 selama eksaserbasi berhubungan dengan total 
jumlah sel, jumlah eosinofil dan limfosit; sedangkan level IL-8 berhubungan dengan semua meningkatnya total jumlah sel, neutrofil dan makrofag. Namun ternyata masih dimungkinkan bahwa pemeriksaan menggunakan sputum masih dapat terkontaminasi kuman orofaring sehingga menurut beberapa ahli pemeriksaan ini mempunyai nilai diagnostik yang rendah dan kurang akurat. $^{3}$

\section{PEMBAHASAN}

Dengan mengetahui adanya kekurangan pada penggunaan sputum sebagai cara untuk mendeteksi PPOK, maka digunakan saliva sebagai pemeriksaan alternatif yang dapat dipakai untuk mendeteksi dini adanya resiko PPOK pada penderita periodontitis. Alasan penggunaan sampel saliva dalam deteksi dini resiko PPOK adalah pengambilan saliva yang jauh lebih mudah, non-invasif dan jumlah produksi saliva yang cukup banyak. Variabelvariabel yang digunakan dalam deteksi dini resiko PPOK melalui saliva antara lain: $P$. gingivalis merupakan bakteri patogen rongga mulut yang dapat berpartisipasi dalam patogenesis infeksi saluran nafas. Mekanisme masuknya $P$. gingivalis yang terdapat pada saliva adalah akibat teraspiranya bakteri patogen tersebut ke dalam saluran nafas bawah, sehingga menimbulkan infeksi. Dengan adanya keterkaitan $P$. gingivalis dalam saliva sebagai salah satu bakteri penyebab PPOK, maka bakteri tersebut dapat digunakan sebagai variabel yang akan diuji dalam deteksi adanya PPOK pada subjek yang akan diteliti. Untuk mengetahui adanya $P$. gingivalis dalam saliva dilakukan uji disk diffusion. Sebelum pemeriksaan, produksi saliva dirangsang selama 5 menit menggunakan permen karet tanpa aroma dan tidak berasa. Saliva kemudian diinokulasikan kedalam media agar Muller Hinton setebal 4 $\mathrm{mm}$ dan diinkubasi selama 24 jam pada suhu 35-37 ${ }^{\circ} \mathrm{C}$. Hasil koloni dilakukan uji pewarnaan Gram untuk menemukan bakteri gram negatif. Bakteri yang dianggap sebagai penyebab PPOK adalah bila bakteri tersebut tumbuh pada konsentrasi lebih dari $10^{6} \mathrm{CFU} /$ $\mathrm{ml}^{3}$

Enzim sialidase merupakan enzim hidrolitik dalam saliva yang menghidrolisa residu asam sialat terminal dari sialioglycoconjugates. Pada penderita PPOK, individu dengan kebersihan mulut yang buruk menyebabkan meningkatnya level enzim sialidase dalam saliva. Dari kondisi tersebut, enzim sialidase sebagai salah satu variabel yang dapat digunakan untuk deteksi dini PPOK. Untuk mengetahui level enzim sialidase yang dapat dianggap sebagai tanda terjadinya PPOK, maka dilakukan pengujian menggunakan enzyme-linked immunosorbent assay (ELISA).

Interleukin-8 adalah suatu kemokin yang terlibat dalam migrasi dan aktivasi dari neutrofil dan eosinofil. Pada penderita PPOK dapat ditemukan IL-8 yang dihasilkan dari jaringan mulut seperti cairan krevikular gingival yang keluar dari sulcus gingival dan bercampur dengan saliva. Kandungan IL-8 dalam saliva dapat digunakan sebagai deteksi dini melalui pengujian menggunakan sandwich immunoassay. Konsentrasi level IL8 pada pasien PPOK secara signifikan lebih tinggi dari individu normal yaitu pada penderita PPOK konsentrasi IL-8 sejumlah $21,0 \pm 1,8 \mathrm{ng} / \mathrm{ml}$ dan kondisi pada individu normal sejumlah $3,3 \pm 0,7 \mathrm{ng} / \mathrm{ml} .{ }^{17}$ Hubungan $P$. gingivalis, enzim Ssialidase, dan IL-8 pada saliva terhadap PPOK dijelaskan bahwa bakteri patogen P.gingivalis yang teraspirasi ke saluran nafas bawah melepaskan enzim protease yang dapat membuka reseptor adhesi pada permukaan mukosa untuk dapat berikatan dengan bakteri patogen saluran nafas seperti H.influenza, namun demikian tubuh memberikan mekanisme pertahanan berupa keluarnya mucin sebagai pertahanan tubuh non-spesifik dalam saliva dengan mengikat $H$. influenza yang melibatkan adanya residu asam sialat. Tetapi dengan kondisi $\mathrm{OH}$ yang buruk pada penderita 
PPOK, memungkinkan meningkatnya enzim sialidase yang dapat menghidrolisis asam sialat dan menghancurkan mucin, sehingga kondisi tersebut menyebabkan meningkatnya kemampuan $H$. influenza untuk menginfeksi permukaan mukosa saluran nafas. Sebagai respon terhadap adanya bakteri tersebut tubuh mengeluarkan sitokin yang berasal dari cairan krevikular gingiva berupa IL-8 untuk meningkatkan pengaturan ekspresi resptor adhesi dan kolonisasi bakteri patogen saluran nafas. Gambar 2 memperlihatkan alur penggunaan saliva sebagai material biologis yang dapat digunakan untuk deteksi resiko PPOK pada pasien dengan periodontitis.

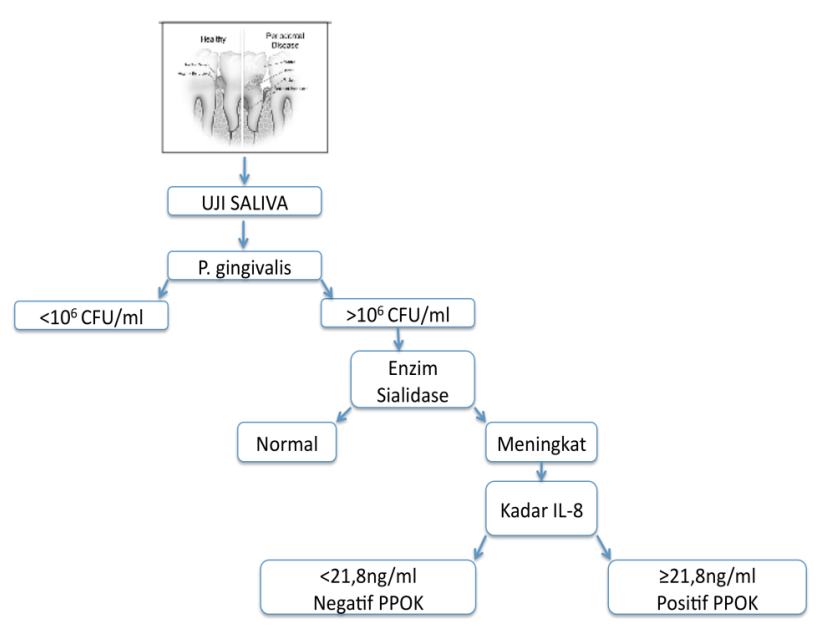

Gambar 2. Skema deteksi dini PPOK dengan saliva

\section{SIMPULAN}

Dari hasil pembahasan yang diuraikan dalam karya ilmiah ini, disimpulkan bahwa saliva dapat diajukan untuk digunakan sebagai deteksi dini resiko PPOK pada penderita periodontitis. Saliva pada individu penderita periodontitis dengan resiko PPOK ditemukan adanya peningkatan jumlah bakteri $P$. gingivalis, level enzim sialidase dan konsentrasi IL-8. Maka dilakukan pengujian bakteri $P$. gingivalis melalui uji disk diffusion, level enzim sialidase melalui uji ELISA serta konsentrasi IL-8 melalui uji sandwich immunoassay dalam saliva. Masih diperlukan penelitian lebih lanjut mengenai penggunaan deteksi dini resiko PPOK pada penderita periodontitis menggunakan saliva sehingga metode ini dapat diterapkan dan diaplikasikan.

\section{DAFTAR PUSTAKA}

1. Rose LF, Genco RJ, Cohen DW, Mealey BL. Periodontal medicine. London: B.C. Decker; 2000.

2. Perhimpunan Dokter Paru Indonesia. Penyakit paru obstruktif kronik (PPOK), pedoman diagnosis \& penatalaksanaan di Indonesia. Jakarta. 2003 Available from: http://www.klikpdpi.com/ konsensus/konsensus-ppok/ppok.pdf. Indonesian.

3. Setiyanto H, Yunus F, Soepandi PZ, Wiyono PH, Hartono S, Karuniawati A. Pola dan sensitivitas kuman PPOK eksaserbasi akut yang mendapat pengobatan Echinacea purpurae dan antibiotik siprofloksasin. J Respir Indo. 2008; 28(3):107-8. Available from: http://isjd.pdii.lipi.go.id/admin/ jurnal/28308107125.pdf. Indonesian.

4. Prasojo, Joko. 2004. Hubungan antara gejala bronkial dengan kejadian penyakit paru obstruktif kronik pada perokok. [thesis]. Bagian Ilmu Penyakit Dalam: Fakultas Kedokteran Universitas Diponegoro. 2004. Available from: http:// eprints.undip.ac.id/12377/1/2004PPDS3621.pdf. Indonesian.

5. Viegi G, Pistelli F, Sherrill DL, Maio S, Baldacci $\mathrm{S}$, Carrozzi L. Comprehensive management of End-Stage COPD. Eur Res J. 2007;30(5): 9931013. doi: 10.1183/09031936.00082507. Available from: http://erj.ersjournals.com/ content/30/5/993.full.pdf.

6. Scannapieco FA. Role of oral bacteria in respiratory infection. J Periodontol. 1999; 70(7):793802 .

7. Mojon P. Oral health and respiratory Infection. J Can Dent Assoc. 2002;68(6):340-5.

8. ILUNI FK 1983. Kesehatan paru. [cited 2012 April 9]. Available from: http:// www.ilunifk83.com/. Indonesian.

9. Garcia RI, Nunn ME, Vokonas PS. Epidemiologic associations between periodontal disease and chronic obstructive pulmonary disease. Ann Periodontol. 2001;6(1):71-7.

10. Brosky ME. The role of saliva in oral health : strategies for prevention and management of xerostomia. J Support Oncol. 2007;5(5):215-25.

11. Mjor MA. Embriologi dan histologi rongga Mmulut. Alih Bahasa. Fazwishni Siregar. Jakarta: Penerbit Buku Kedokteran Widya Medika;1991.

12. Amerongen AVN. Ludah dan kelenjar ludah anti bagi kesehatan gigi. Alih Bahasa. Yogyakarta: Gadjah Mada University Press; 1992.

13. Duncan M, Dewhirst F, Chen T. The Porphyromonas gingivalis genome project. [cited 2012 